\title{
Occupational human capital and earnings losses of displaced workers: does the degree of similarity between pre- and post- displacement occupations matter?
}

\author{
Kritkorn Nawakitphaitoon $\cdot$ Russell Ormiston
}

Published online: 27 August 2014

(C) Institut für Arbeitsmarkt- und Berufsforschung 2014

\begin{abstract}
This paper examines the effect of accumulated human capital, and particularly occupational human capital, on the earnings losses of displaced workers. Unlike most of the previous studies of job displacement, this paper uses a continuous measure of occupational skills transferability to measure the similarity between the pre- and post-displacement occupations of reemployed displaced workers. Using the 2004, 2006, 2008, and 2010 Displaced Worker Survey (DWS), the main finding is that post-displacement earnings losses are highly correlated with the degree of similarity between pre- and post-displacement occupations. Displaced workers who find jobs in occupations similar to their previous jobs suffer smaller earnings losses than those who find less similar jobs. This relationship is non-linear in that higher skills transferability reduces the earnings losses at a decreasing rate as the transferability of occupational skills increases.
\end{abstract}

Keywords Job displacement - Occupational human capital $\cdot$ Skills transferability $\cdot$ Earnings losses

JEL classification J31 $\cdot \mathrm{J} 62 \cdot \mathrm{J} 63$

K. Nawakitphaitoon $(\square)$

School of Labor and Human Resources,

Renmin University of China,

100872 Beijing, China

e-mail: kengha_di@hotmail.com

R. Ormiston

Department of Economics, Allegheny College,

Meadville, PA 16335, USA
Berufliches Humankapital und Einkommensverluste von freigesetzten Arbeitskräften: Wie sehr kommt es darauf, dass sich die Beschäftigungsverhältnisse vor und nach dem Arbeitsplatzverlust ähneln?

Zusammenfassung In dieser Arbeit werden die Auswirkungen akkumulierten Humankapitals, insbesondere beruflichen Humankapitals, auf die Einkommensverluste freigesetzter Arbeitskräfte untersucht. Abweichend zu den meisten früheren Studien zu Arbeitsplatzverlusten nutzt diese Arbeit die durchgängige Messgröße der Übertragbarkeit beruflicher Kenntnisse, um die Ähnlichkeit von Beschäftigungen vor und nach dem Arbeitsplatzverlust von wiederbeschäftigten freigesetzten Arbeitskräften zu messen. Unter Nutzung der Displaced Worker Survey (DWS) der Jahre 2004, 2006, 2008 und 2010 ist die wichtigste Erkenntnis dieser Arbeit, dass Einkommensverluste nach einem Arbeitsplatzverlust eine starke Korrelation mit dem Ähnlichkeitsgrad zwischen den Beschäftigungen vor und nach dem Arbeitsplatzverlust aufweisen. Freigesetzte Arbeitskräfte, die Beschäftigungen finden, die ihren früheren Beschäftigungen ähneln, haben geringere Einkommensverluste als diejenigen, die weniger ähnliche Beschäftigungen finden. Diese Beziehung ist insofern nicht linear, als eine höhere Übertragbarkeit von Kenntnissen die Einkommensverluste bei steigender Übertragbarkeit von beruflichen Kenntnissen in sinkendem Maße reduziert. Die weitere Analyse zeigt außerdem die positive Beziehung zwischen Einkommen vor dem Arbeitsplatzverlust und dem Grad der beruflichen Ähnlichkeit.

Schlüsselwörter Verlagerung von Arbeitsplätzen · Berufliches Humankapital · Übertragbarkeit von Kompetenzen · Einkommensverluste 


\section{Introduction}

The costs of job displacement have received considerable attention from policy makers and researchers in previous decades. The recent recession and the resulting dramatic increase in involuntary job losses have increased interest in this issue. Millions of prime-age workers have been displaced, and those fortunate enough to find employment have often suffered substantial reductions in earnings. Studies of the U.S. labor force have indicated that displaced workers suffer a large and persistent loss of earnings (for example, Ruhm 1991; Jacobson et al. 1993; Kletzer and Fairlie 2003). Ruhm (1991) found that the weekly earnings of displaced workers were $16 \%$ lower than those of non-displaced workers 1 year following the displacement. Four years after displacement, their earnings remained $14 \%$ below their former earnings. Given the large and ongoing losses suffered by displaced workers, it is important to determine the factors affecting the magnitude of earnings losses associated with displacement.

The goal of this paper is to investigate the effect of accumulated human capital, and particularly occupational human capital, on earnings losses. Specifically, to what extent does the similarity between pre- and post-displacement occupations affect the earnings losses of the displaced workers? We hypothesize that the earnings losses associated with displacement are affected by the degree to which occupation-specific skills can be transferred across occupations. Among reemployed workers following displacement, we predict those who switch to a closer (more similar) occupation will suffer smaller earnings losses than those who switch into a dissimilar occupation, as they lose fewer of their occupation-specific skills. Unlike most of the previous studies of job displacement, we use a continuous measure of occupational skills transferability to measure the similarity between pre- and post-displacement occupations of reemployed displaced workers.

This paper uses the data from the 2004, 2006, 2008, and 2010 Displaced Worker Survey (DWS) biennial supplement to the Current Population Survey (CPS) to estimate the portion of earnings losses attributable to lack of occupational skills transferability. This dataset contains the retrospective data on both pre- and post-displacement labor market circumstances, including occupations, for a large sample of workers who lost their jobs over the period of 2001-2009. The O*NET dataset is used to estimate the measure of occupational similarity applied in the analysis of earnings losses.

The main findings of this paper show that post-displacement earnings losses are highly correlated with the degree of similarity between pre- and post-displacement occupations. Displaced workers who find jobs in occupations similar to their previous jobs, as measured by occupational skills transferability, suffer smaller earnings losses than those who find less similar jobs. For example, displaced workers whose new jobs measure 10 percentage points closer to their previous job on the occupational similarity measure experience approximately 3.6 percentage points fewer earnings losses. In addition, this relationship is non-linear: higher skills transferability reduces earnings losses at a decreasing rate. The further analysis also shows the positive relationship between pre-displacement earnings and the degree of occupational similarity. These findings provide important insight into the determination of earnings losses following job displacement. In particular, from a theoretical perspective, this research contributes to the human capital literature by emphasizing the importance of occupational human capital and the idea that occupational skills are (partially) transferable across occupations.

The structure of this paper is as follows. Section 2 summarizes the literature on the role of human capital, particularly occupational human capital, in earnings losses due to displacement. Section 3 explains the estimation of an index of occupational similarity, and Sect. 4 sets up the methodological framework. Section 5 describes the main dataset and related variables, and Section 6 discusses the descriptive statistics. Section 7 presents the main findings and robustness tests. The last section concludes and discusses some of the implications for future research.

\section{Literature review}

In general, a displaced worker is defined as someone who is involuntarily separated from his or her job as a consequence of economic factors and business decisions of employers that are beyond the control of the workers. Those who lose jobs because of individual job performance or who decide to voluntarily quit are not considered displaced workers. Studies of the U.S. labor force generally agree that displaced workers earn less in their post-displacement jobs than their original jobs (for example, Jacobson et al. 1993; Kletzer and Fairlie 2003); however, they differ in their estimates of the amount of earnings losses and provide little insight into the sources of earnings losses. The differences in estimates across studies could be due to differences in the data used or the methodology, or the discrepancies could simply reflect unexplained variance in the earnings losses workers experience. ${ }^{1}$

\footnotetext{
${ }^{1}$ The empirical studies of earnings losses after job displacement in Europe had also been burgeoning. Overall, the studies also found that displaced workers who experience a period of unemployment suffer the earnings losses (Burda and Mertens 2001; Couch 2001; Hijzen et al. 2010). For example, Couch (2001) used the German Socioeconomic Panel (GSOEP) from 1988 to 1996 and found that the annual earnings of displaced workers in Germany were $13 \%$ lower 1 year following the displacement. Two years after displacement, their earnings were around $6.5 \%$ below their former earnings. Hijzen et al. (2010)
} 
There are many factors in the previous literature that were proposed and tested empirically to explain the earnings losses of displaced workers, including human capital attributable to a job, unionization, job quality match, and local market conditions (Topel 1990; Carrington 1993; Kletzer 1998). In this section, we review studies based on the human capital theory, particularly occupational human capital. The idea that human capital is an important determinant of earnings is not new. The human capital model proposed by Becker (1964) categorizes human capital skills into two types. The first type of human capital is "general human capital," which is defined as skills that are productive and completely transferable across different firms and usually measured as years of labor market experience. The second is "firm-specific human capital," which is defined as skills that are productive at only one firm, generally measured as years of work in the current firm, and not transferable across firms. On the one hand, if human capital skills are "general" in the case of being transferable across firms, then the effect of displacement on earnings losses should be minor. On the other hand, if firm-specific skills are important for determining earnings losses, then workers with high levels of firmspecific skills who are displaced from their jobs are likely to experience large earnings losses. Most previous studies find that earnings following job displacement are strongly correlated with pre-displacement years of work experience and job tenure (for example, Podgursky and Swaim 1987; Topel 1990; Carrington 1990; Faber 1993). ${ }^{2}$

More recent literature on job displacement has started to explore the importance of other dimensions of human capital and to emphasize that workers' earnings likely depend on skills that are not completely general or firm-specific but instead specific to the worker's industry or occupation. Several studies have found that some skills are transferable within but not between industries (for example, Podgursky and Swaim 1987; Carrington 1993; Neal 1995). In particular, the post-displacement earnings of workers who change industries are lower than those who could find a new job in the same industry. For example, Neal (1995) found that displaced workers who switch between 1-digit industries following displacement, on average, suffer greater wage losses than those who find new jobs in their pre-displacement industry. In addition, the post-displacement wages among

applied a matched employer-employee dataset in the U.K. and found that workers who lose their jobs because of a mass layoff, on average, suffer a loss of $14-25 \%$ of their income.

${ }^{2}$ Another explanation for why high-tenure workers are more likely than others to experience large earnings losses, in addition to losing firmspecific human capital, is the concept of deferred compensation (delayed payment contracts). In particular, displaced workers' earnings losses will be higher if, in their previous jobs, they had accepted wages below their level of productivity at the beginning in return for higher earnings in the latter part of the career (Lazear 1979, 1981; Hutchens 1989). displaced workers who stay in their old industry increase more sharply with pre-displacement tenure and years of labor market experience than among those who switch industries.

There are also several studies that have considered the importance of occupational human capital in explaining earnings losses (Carrington 1990; Topel 1990; Kambourov and Manovskii 2009). For example, Kambourov and Manovskii (2009) demonstrated that:

On average, a currently employed worker who was displaced from a job in the preceding 5 years suffers a $15 \%$ reduction in weekly earnings. However, those who stay in the same occupation after the displacement only suffer a $6 \%$ drop in their weekly earnings, even after controlling for the pre-displacement firm tenure whereas those who switch their occupation experience an $18 \%$ drop. (p. 63)

Thus, there is a growing body of evidence that some human capital is specific to occupation and industry. These empirical results are taken as evidence to support the idea that displaced workers who regain employment in the same occupation or industry are more likely to be able to keep using more of their human capital, and so suffer lower earnings losses.

The aforementioned studies usually characterize occupations or industries upon reemployment as either "the same" or "different," generally using a dummy variable and either the 1-, 2-, or 3-digit level industrial or occupational classifications. This approach inherently assumes that workers who could not find a job in their previous occupational or industrial category will lose all of their occupation- or industryspecific skills. However, in reality, at least some skills are likely to be transferred across occupations. For example, an engineer who is displaced from his old job and gets a new job as a clerk should be able to apply some portion of his engineering skills to a clerical job.

The idea of occupational skills transferability was first introduced by Shaw (1984). She defined the concept of occupational human capital as "individual investment in skills which relate to one particular occupation, and he/she would be able to transfer a certain amount of his/her occupation skills during the occupational switch depending on the "transferability' between those two occupations" (pp. 320-321). More specifically, Shaw notes that the return to the stock of human capital from the former occupation is not completely foregone upon during an occupational switch. Instead, the return to one's human capital stock depends on the degree of transferability of skills from one occupation to the next. In spite of Shaw's findings and contributions, only a few recent studies, particularly on the job displacement, have started to focus on the importance of skills transferability. For instance, Ormiston (2006) developed an occu- 
pational skills transferability index and showed that there is a positive relationship between skills transferability and occupational movement as well as post-displacement earnings among blue-collar workers. ${ }^{3}$ In particular, he found that displaced blue-collar workers are more likely to choose a new occupation with high skills transferability. Schönberg and Gathmann (2010) use the repeated cross-section German Qualification and Career Survey to estimate the transferability of three aggregate groups of skills (analytical, manual, and interactive) across 64 occupations in the German labor market. Their results show that workers are more likely to move to occupations with similar skill requirements, and more than $40 \%$ of their wage growth can be attributed to the proportion of these portable skills. In addition, there is an increase in earnings losses for the displaced workers who moved to a distant occupation after a job displacement.

With few exceptions, the important contributions from most previous studies have focused on the role of occupation-specific skills (i.e., skills that would be lost or not be applicable whenever workers change occupations) and neglect the idea that skills could be transferred across occupations. Ignoring skills transferability might result in a misleading estimate of the effect of occupational human capital on earnings losses of displaced workers. This study, therefore, applies Shaw's ideas that skills specific to a given occupation are transferable to similar occupations but have limited transferability to dissimilar occupations and uses the methodology developed in Ormiston (2006) to estimate the skills transferability. In particular, we hypothesize that workers should experience fewer (more) earnings losses when reemployed in occupations that are more (less) similar to their old jobs. The results of this study, therefore, should add assessments of explanations for the displaced workers' earnings losses discussed above.

\section{The estimation of occupational similarity}

This paper uses the "occupational skills transferability" proposed by Ormiston (2006) as a measure of similarity between pre- and post-displacement occupations. ${ }^{4}$ Ormiston

\footnotetext{
${ }^{3}$ His study mainly focuses on blue-collar occupations that include: transportation and material moving; production; installation, maintenance, and repair; construction and extraction; and farming, fishing, and forestry.

${ }^{4}$ Shaw (1984) also developed a measure of occupational skills transferability by examining the occupational movement across years using the Current Population Survey (CPS). However, this method introduces a significant amount of noise due to the occupational coding errors of the CPS (Kambourov and Manovskii 2004). In addition, it assumes skills transferability to be symmetric, in which the skills transferability from occupation $i$ to $j$ is equal to the skills transferability from occupation $j$ to $i$. In other words, the direction of the skills transfer is irrelevant. Ormiston's skills transferability, on the other hand, is a non-symmetric
}

Table 1 Score categories used to calculate occupational skills transferability

\begin{tabular}{llll}
\hline Occupation (SOC) & \multicolumn{3}{l}{ Score of three selected knowledge categories } \\
\cline { 2 - 4 } & $\begin{array}{l}\text { Administration } \\
\text { and management }\end{array}$ & $\begin{array}{l}\text { Engineering and } \\
\text { technology }\end{array}$ & $\begin{array}{l}\text { Sales and } \\
\text { marketing }\end{array}$ \\
\hline $\begin{array}{l}\text { HR manager } \\
(11-3040.00)\end{array}$ & 19.68 & 1.03 & 5.99 \\
$\begin{array}{l}\text { Industrial engineer } \\
(17-2112.00)\end{array}$ & 16.01 & 23.50 & 9.76 \\
\hline
\end{tabular}

(2006) develops a method of estimating the occupational skills transferability that directly measures the skill content of jobs. In particular, he estimates the skills transferability based on the knowledge, skills, and abilities (KSAs) shared across occupations. The skills transferability measure is an estimated proportion of occupation-specific human capital that would be transferred from one's origin occupation to one's destination occupation, and it is derived by the computation of a ratio of shared KSAs between two occupations to the KSAs required within the origin occupation. It is a continuous measure bounded between 0 and 1 . The dataset used to estimate the skills transferability is the O*NET, the authoritative national database on vocational information coordinated by the United States Department of Labor. In particular, it characterizes 900 different occupations based on the 3-digit Standard Occupational Classification (SOC) code along 120 standardized knowledge, skill, and ability categories (KSAs), which are shown in Appendix Table 9.5

Using the KSAs for each occupation, we estimated the skills transferability by calculating the proportion of KSAs that would be transferred from one's origin occupation to one's destination occupation. We did so by computing the ratio of shared KSAs to total KSAs required within the origin occupation. Table 1 provides the knowledge score of an industrial engineer and human resource manager in "Administration and Management," "Engineering and Technology," and "Sales and Marketing" categories. For example, an industrial engineer uses 16.01 points of the administration and management knowledge area, while the human resource manager uses 19.68 points. Within this knowledge category, the two occupations share 16.01 points. While the industrial engineer can apply all 16.01 points of their "Administration and Management" knowledge in his/her role as an HR manager, the HR manager, on the other hand, can apply only a portion of his/her 19.68 points in a role as an industrial engineer, given the smaller requirement of "Administration

method, in which the skills transferability from occupation $i$ to $j$ does not have to be equal to that from occupation $j$ to $i$. Thus, Ormiston's method of skills transferability is preferable in this analysis.

${ }^{5}$ The skills transferability across occupations, developed in this paper, is first based on the SOC and then is matched to the 3-digit occupational categories of the 2000 occupational classification system provided in the CPS. While there are some differences between these two systems, we carefully matched these categories with guidance from the CPS codebook supplement in order to prevent the recoding problems. 
Table 2 Sample occupational skills transferability of HR profession to three selected occupations

\begin{tabular}{llll}
\hline & \multicolumn{3}{l}{ Occupation (SOC) } \\
\cline { 2 - 4 } & $\begin{array}{l}\text { Economist } \\
(19-3011.00)\end{array}$ & $\begin{array}{l}\text { Baker } \\
(51-3011.01)\end{array}$ & $\begin{array}{l}\text { Sales manager } \\
(11-2022.00)\end{array}$ \\
\hline HR manager & 0.7914 & 0.1593 & 0.8661 \\
$(11-3040.00)$ & & & \\
\hline
\end{tabular}

and Management" knowledge in the engineering occupation. Using the transferability estimate outlined above, in this example, the transferability of the "Administration and Management" knowledge category from the industrial engineer position to the HR manager position is equal to 1 (16.01/16.01), while the transferability of the "Administration and Management" knowledge category from the HR manager position to the industrial engineer position is equal to 0.814 (16.01/19.68).

By summing this score within all 120 categories of KSAs for each pair of occupations, and then averaging the totals, ${ }^{6}$ we derived the $467 \times 467$ occupational skills transferability matrix based on the 2000 U.S. Census 3-digit code. ${ }^{7}$ Table 2 provides an example of the occupational skills transferability from HR manager to economist, baker, and sale manager. This suggests that $79.17 \%$ of KSAs used by an HR manager would transfer to the economics profession. On the other hand, only $15.93 \%$ of KSAs would transfer from HR manager to baker. The skills transferability estimated here will be used in the subsequent analysis of occupational human capital and earnings losses following job displacement. ${ }^{8}$

\section{Methodology}

As a first approximation, this paper assumes that workers in the sample were exogenously displaced, and then a subset of them was randomly assigned to new jobs. Of those who end

\footnotetext{
${ }^{6}$ One might have concerns regarding whether averaging KSA categories gives the appropriate weights in cross-occupational comparisons given the presence of a vital KSA in the estimation of occupational skills transferability measure. For example, when thinking about the "medicine and dentistry" knowledge category, this is of utmost importance to surgeons and physicians; without it, no amount of similarity from other KSA categories (e.g., interpersonal communication) means anything. In other words, even if transferability is high, it is relatively useless without high transferability in one specific category. Although it might look suspicious in some particular pairs of occupations, since we still do not know exactly how to appropriately weight each KSA category for each occupational pairing, the overall transferability using the averaging over KSA categories is still applicable.

${ }^{7}$ A complete occupational skills transferability matrix is available from the authors.

${ }^{8}$ Nawakitphaitoon (2014) applied this measure to examine the role of occupational skill transferability in the determination of worker's wages and found that occupational skills from the previous jobs also affect the worker's wages at the current job.
}

up in a new job, assume some are in occupations that are similar to their pre-displacement occupation, and others are not. ${ }^{9}$ If these assumptions are true, then the ordinary least square (OLS) regression will provide unbiased and consistent estimators. Equation 1 is the baseline specification for estimating the impact of occupational similarity on earnings losses.

$$
\Delta \ln W_{i}=\beta_{0}+\beta_{1} \text { Transfer }_{i, i c}+\beta_{2} \text { Transfer }_{i, i c}^{2}+\gamma^{\prime} X+\varepsilon_{i}
$$

$\Delta \ln W_{i}$ is the difference in the natural logarithm of real weekly earnings between pre- and post- displacement jobs for individual $i,{ }^{10}$ and negative values of this variable indicate larger earnings losses. Transfer ${ }_{i, l c}$ and Transfer $_{i, l c}^{2}$ are the measures of occupational similarity indicating the skills transferability between pre- and post-displacement occupations (i.e., from occupation/to occupation $c$ ). The success of finding a job similar to the previous occupation after an involuntary job loss is also driven by a lot of other dimensions, such as the individual characteristics, the number of available vacancies in the year of job loss, and the possibility for geographical mobility. To capture some of these aspects, we also include age, gender, marital status, level of education, race, years of tenure at the lost job, ${ }^{11}$ year dummies indicating when the job was lost during the 3-year spell, 1-digit occupation and industry dummies of the lost job, ${ }^{12}$ a geographical mobility dummy, and work history variables as the control variables $(X)$ (see Appendix Table 10 for a complete summary of all control variables included in the estimation). Studies in this literature also often control for labor market experience using the proxy variable potential experience (age-education-six) since the DWS lacks the measure of an actual year of market experience. However, given the change in the measure of education in the DWS after the 1992 survey from an actual year of education to education level, we opt for using worker age and education level instead. In particular, all else equal, workers with higher ages are likely to obtain more general labor market

\footnotetext{
${ }^{9}$ However, these workers might not represent a random sample of displaced workers because the probability of being displaced may differ across occupations.

${ }^{10}$ The real weekly earnings are measured in \$2010. Also, since the dependent variable is in the log form, the estimated coefficients could be interpreted as percentage changes in earnings losses due to the job displacement.

${ }^{11}$ This variable partially accounts for the fact that some displaced workers have remained in their pre-displacement job longer than others. If we believe that skills accumulate over time and partially transferable across occupations, earnings losses would be higher for workers with high tenure in their pre-displacement job.

${ }^{12}$ The choice of the initial occupation may also be relevant because displacement may be explained by initially choosing a "bad" occupation so that the probability of finding a similar occupation after displacement may be lower. Thus, we control for the 1-digit occupation dummies of the lost job in the estimation. The same logic also applies to the choice of the initial industry.
} 
experience, which will not be lost during a job change and therefore will help lower their earnings losses. In addition, we include the unemployment rate during the year of the survey across states and a dummy variable indicating the year of displacement as proxies for labor market conditions that could affect the opportunities for displaced workers to find new jobs. ${ }^{13} \varepsilon_{i}$ is an error term with mean zero and constant variance, and it is assumed to be independent and identically distributed across individuals.

Thus, $\beta_{1}$ and $\beta_{2}$ in Eq. 1 are of central interest, and these are interpreted as the estimated effect of occupational similarity on earnings losses. If the transferability of occupational skills is important for determining the earnings losses, post-displacement earnings should be higher for reemployed workers who find occupations more similar to their old jobs. This means we should expect $\beta_{1}$ to be positive. In addition, even if greater occupational similarity does reduce earnings losses on average, there is reason to expect diminishing returns to similarity. Specifically, workers who find a very dissimilar occupation have more to gain, in terms of post-displacement earnings, by obtaining a slightly more similar occupation than those who have already found a very similar occupation. In other words, the return to one additional unit of skills transferability will be higher for displaced workers who find post-displaced employment in an occupation with a low value of skills transferability (i.e., in a very dissimilar occupation) than those who have already found a closer match. In particular, if the above hypothesis is correct, $\beta_{2}$ should be negative.

Next, we compare the contribution of the skills transferability measure (i.e., a continuous variable bounded between 0 and 1) to the dichotomous occupational change measure commonly used in previous studies of occupational human capital. The dichotomous measure is equal to 1 if an individual changes occupations and 0 otherwise. We hypothesize that the continuous measure of occupational skills transferability will add information to the model and explain more of the variation in earnings losses than the dichotomous measure. To test this hypothesis, we estimate the following regressions:

$$
\begin{gathered}
\Delta \ln W_{i}=\beta_{0}+\delta_{1} \text { SAMEOCC }_{i}+\gamma^{\prime} X+\varepsilon_{i} \\
\begin{array}{c}
\Delta \ln W_{i}=\beta_{0}+\beta_{1} \text { Transfer }_{i, i c}+\beta_{2} \text { Transfer }^{2} \\
i, i c \\
+\delta_{1} \text { SAMEOOC }_{i}+\gamma^{\prime} X+\varepsilon_{i}
\end{array}
\end{gathered}
$$

According to the above hypothesis, one would expect that the inclusion of skills transferability (Transfer $r_{i, l c}$ and $\operatorname{Transfer}_{i, l c}^{2}$ )

\footnotetext{
${ }^{13}$ Carrington (1993) introduced more diverse measures of local market conditions for pre-displacement occupations and industry markets for workers, and he found that these local market conditions can also explain some of the wage losses encountered by displaced workers.
}

in Eq. 3 would decrease the magnitude of the coefficient on the dichotomous measure (SAMEOCC) as compared to the estimate from Eq. 2. In addition, the adjusted $R^{2}$ of Eq. 2 should be lower than that of Eq. 1 .

The preceding analysis relies on the two key assumptions laid out at the beginning of this section: (1) workers are exogenously displaced and (2) a random subset of workers is (randomly) assigned to new jobs. If these assumptions do not hold, the magnitudes of the estimated coefficients from the OLS regression might be misleading because of the selection bias. In particular, the sample in this analysis only includes displaced workers who had become reemployed by the time of the survey. Therefore, the estimated relationship between the skills transferability across occupations and earnings losses in this sample may be quite different from the relationship observed in the labor force as a whole, which includes both reemployed and un-reemployed workers. To account for possible selection bias, we use the sample restriction suggested in Neal's (1995) study. The detail of this strategy is discussed along with the results.

\section{Dataset}

To examine the effect of the transferability of occupational human capital skills on earnings losses following job displacement, we used the 2004, 2006, 2008, and 2010 Displaced Workers Survey (DWS), ${ }^{14}$ which is a supplement to the January Current Population Survey (CPS). The DWS has been widely used in studies of displaced workers because of the comprehensiveness of its questions about the incidence and cost of job displacement. In particular, displaced workers in the DWS are identified based on a question in the CPS that asks, "During the last three calendar years, did you lose a job or leave one because: (1) the plant or company is closed or moved, (2) your position or shift is abolished, or (3) there is insufficient work?"15 If the answer from the respondent is "yes," they will be asked a series of questions regarding the lost job and current job (if they have been reemployed during the current survey). ${ }^{16}$ Since each survey year collects information on job loss that includes 3 years of job displacement prior to the survey date, both surveys

\footnotetext{
${ }^{14}$ The data is publicly available at Center for Economic and Policy Research. 2011. CPS Displaced Worker Uniform Extracts, Version 1.02. Washington, D.C. (http://www.ceprdata.org/cps/dws_prog.php).

${ }^{15}$ Prior to 1996 , the DWS had a 5-year recall period; besides, there is a slight discontinuity in the definition of displaced worker in the survey from 1984 to 1992 and 1994 to 2004, as earlier surveys failed to inquire whether a person was expecting a recall from his/her lost job. Therefore, this study uses the DWS starting from 2004 to 2010.

${ }^{16}$ If more than one job was lost during the pre-displacement period, information was obtained from the job held for the longest time.
} 
provide information about workers who lost their jobs from 2001 (for the 2004 survey) to 2009 (for the 2010 survey).

One disadvantage of this dataset is that it is cross-sectional, which means that all pre-displacement job information is gathered through retrospective questions in the DWS. Retrospective data is subject to "recall bias." For the DWS, displaced workers are asked to recall job history information over the past 3 years. This raises concerns that respondents may either understate or overstate the effects of job displacement. ${ }^{17}$ Another concern about the use of the survey-based data sets, including the DWS, is that they do not commonly allow the construction of an appropriate comparison group of non-displaced workers to estimate the counterfactual wage development for displaced workers, resulting in the underestimation of earnings losses of displaced workers (Jacobson et al. 1993). ${ }^{18}$

However, a major advantage of this dataset, particularly when compared to other datasets such as the National Longitudinal Survey of Youth (NLSY) or the Panel Study of Income Dynamics (PSID), is that it is a very large dataset drawn from a random sample of over 60,000 households. It is weighted to be representative of the U.S. population, and the measures in the dataset are straightforward (Kletzer 1998). In addition, the 3-year interval of information collected on job displacement in the DWS also provides the data to determine variations in the amount of time since displacement at the time of interview (Carrington 1990).

The DWS provides pre- and post-displacement 3-digit U.S. census occupation codes and weekly earnings that we used in the regression analysis. Specifically, the pre- and postdisplacement 3-digit occupations are compared to attach the value of skills transferability. The sample in this analysis includes individuals who are between the ages of 20 and 62 who were reemployed at the time of the survey. ${ }^{19}$ There were 27,540 workers displaced between 2001 and 2009. Of those displaced workers, 20,713 were excluded from this sample because they were not reemployed by the time of survey, or they did not supply data on the key variables such as

\footnotetext{
${ }^{17}$ For a more careful discussion about the recall bias of DWS, see Evans and Leighton (1995) and Kletzer (1998).

${ }^{18}$ Previous literature also suggests that the measurement point of earnings is decisive for the calculation of the earnings losses (Jacobson et al. 1993). In particular, if one attributes the pre-separation earnings losses to the displacement, then calculating the earnings losses associated with displacement as the difference in earnings in the year prior to displacement and the earnings after displacement would lead to an underestimation of earnings losses. Because of the limitations of the DWS, this study restricts the analysis to the post-displacement losses of displaced workers and compares earnings prior to separation to earnings once the workers are reemployed.

${ }^{19}$ The typical reason to exclude workers above age 62 is because these workers will, in general, be qualified for social security retirement payments and therefore might encounter the different set of constraints in the labor marker than the younger workers (Podgursky and Swaim 1987).
}

pre- and post-displacement occupations. We also excluded displaced workers who served in the military or were selfemployed for either pre- or post-displacement jobs. ${ }^{20}$ Our final sample, therefore, consists of 6827 individuals.

\section{Descriptive statistics}

Appendix Table 10 presents the summary statistics of the variables used in this analysis for the sample pooling across the 2004-2010 surveys. The first row of Appendix Table 10 shows the mean changes in real weekly earnings (in \$2010) between pre- and post-displacement jobs. On average, displaced workers earned 0.21 percentage points less when reemployed than in their pre-displacement job. The 0.21 percentage points translate to around a $\$ 121$ loss in weekly earnings. The typical employee had worked for their former employer for 5 years, and $90 \%$ of the workers in the sample worked full-time at the lost job. A majority of workers in this sample were white and relatively old (around 40 years old). $58 \%$ of the sample received health insurance from their former employer; $43 \%$ qualified for unemployment insurance benefits.

Our sample excludes around $75 \%$ of displaced workers from the full sample in the DWS because they did not supply data on the key variables, Appendix Table 11, therefore, presents descriptive statistics of these displaced workers compared to those of the full sample of displaced workers in the DWS. Overall, the workers in our sample did not differ greatly from the full sample. For example, the average weekly earnings at the current job of those in the displaced workers sample were slightly higher than those in the full sample (i.e., \$685.01 vs. \$677.47), and the differences in gender, race, and age were quite small between the two samples. The results of this comparison are reported in Appendix Table 11.

Table 3 presents the proportion of reemployed workers who were displaced between 1991 and 2009 and found a different (3-digit) occupation from the previous job. Most displaced workers who were reemployed at the survey date (from 1994 to 2010) could not find the same 3-digit occupations in reemployment. Close to $70 \%$ of the reemployed workers ended up working in different occupations from their old jobs.

Next, Fig. 1 displays the distribution of occupational skills transferability among reemployed displaced workers. In particular, it shows that there is substantial variation in skills transferability. The average skills transferability is

\footnotetext{
${ }^{20}$ The primary reason to exclude self-employed workers is due to the differences in the formation of their wages, and it is also difficult to see how the idea of an exogenous displacement could be applied to self-employed workers.
} 
Table 3 Percentage of reemployed workers who change occupations

\begin{tabular}{llllllllll}
\hline Full sample & 1994 & 1996 & 1998 & 2000 & 2002 & 2004 & 2006 & 2008 & 2010 \\
\hline Different occupation (\%) & 69.74 & 71.12 & 71.26 & 67.43 & 69.35 & 65.52 & 63.88 & 65.60 & 61.72 \\
\hline
\end{tabular}

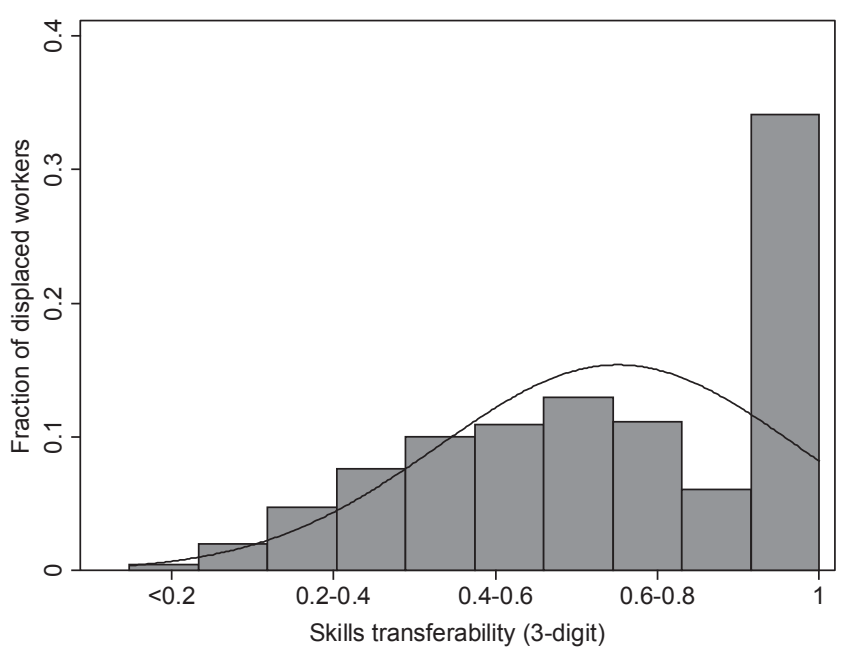

Fig. 1 The fractions of displaced workers by level of skills transferability

around $75 \%$, which means that displaced workers, on average, found a job to which they could transfer $75 \%$ of their previous occupational skills.

Table 4 presents the correlation between the skills transferability and other key variables. For example, the skills transferability is positively correlated with the earnings differences after displacement as well as with the pre-displacement earnings. This implies that not only do earnings differences increase with the degree of occupational similarity, but the pre-displacement earnings also increase with the occupational similarity as well. In addition, the skills transferability has a positive correlation with the education level.
In particular, displaced workers with a college or advanced college degree are likely to switch to more similar occupations, while the less-than high school or high school workers are likely to switch to less similar occupations. Note that the skills transferability and state unemployment rate are positively correlated. This descriptive evidence is inconsistent with the previous literature that found workers who lose their jobs during economic downturns face more difficulties to find new jobs in their pre-displacement occupations.

To determine the relationship between earnings losses and the similarity between pre- and post-displacement occupations, measured by skills transferability, Fig. 2 presents the average changes in the natural logarithm of real weekly earnings (in \$2010) by the level of skills transferability. Although the mean loss resulting from job displacement for the full sample is approximately $21 \%$, Fig. 2 shows that there is a wide dispersion across different levels of skills transferability. It indicates a positive relationship between occupational skills transferability (in the 3-digit level) and the decline of earnings losses. In particular, it shows that higher skills transferability from the previous occupation to the new occupation can help reduce earnings losses due to job displacement. For example, at a skills transferability level between 0.2 and 0.3 points, the average earnings losses were approximately $26 \%$; at skills transferability between 0.3 and 0.4 , they were around $21 \%$. In addition, Fig. 2 illustrates that as the skills transferability increased, the slope of earnings losses became flatter, illustrating the possibility of a non-linear relationship between skills transferability and earnings losses. In other words, the earnings losses are not sensitive to occupational similarity when moving among

Table 4 Correlations between skills transferability and other key variables

\begin{tabular}{|c|c|c|c|c|c|c|c|c|}
\hline & $\begin{array}{l}\text { Skills } \\
\text { transferability }\end{array}$ & $\begin{array}{l}\ln (\text { earnings } \\
\text { difference) }\end{array}$ & $\begin{array}{l}\ln (\text { lost job } \\
\text { earnings })\end{array}$ & $\begin{array}{l}\text { State unem- } \\
\text { ployment }\end{array}$ & $\begin{array}{l}\text { Less than } \\
\text { high school }\end{array}$ & High school & College & $\begin{array}{l}\text { Advanced } \\
\text { college }\end{array}$ \\
\hline $\begin{array}{l}\text { Skills } \\
\text { transferability }\end{array}$ & 1.000 & & & & & & & \\
\hline $\begin{array}{l}\ln \text { (earnings } \\
\text { difference) }\end{array}$ & $0.138^{*}$ & 1.000 & & & & & & \\
\hline $\begin{array}{l}\ln (\text { lost job } \\
\text { earnings) }\end{array}$ & $0.150 *$ & $-0.276^{*}$ & 1.000 & & & & & \\
\hline $\begin{array}{l}\text { State unem- } \\
\text { ployment }\end{array}$ & $0.029 *$ & -0.020 & $0.038 *$ & 1.000 & & & & \\
\hline $\begin{array}{l}\text { Less than } \\
\text { high school }\end{array}$ & -0.008 & 0.006 & $-0.171^{*}$ & 0.015 & 1.000 & & & \\
\hline High school & $-0.073 *$ & $-0.029 *$ & $-0.181 *$ & $-0.028^{*}$ & $-0.204^{*}$ & 1.000 & & \\
\hline College & $0.081 *$ & 0.010 & $0.256^{*}$ & 0.020 & $-0.146^{*}$ & $-0.351 *$ & 1.000 & \\
\hline $\begin{array}{l}\text { Advanced } \\
\text { college }\end{array}$ & $0.110^{*}$ & $0.031 *$ & $0.264 *$ & $0.030 *$ & $-0.079^{*}$ & $-0.188^{*}$ & $-0.135^{*}$ & 1.000 \\
\hline
\end{tabular}

$* p<0.05$ 


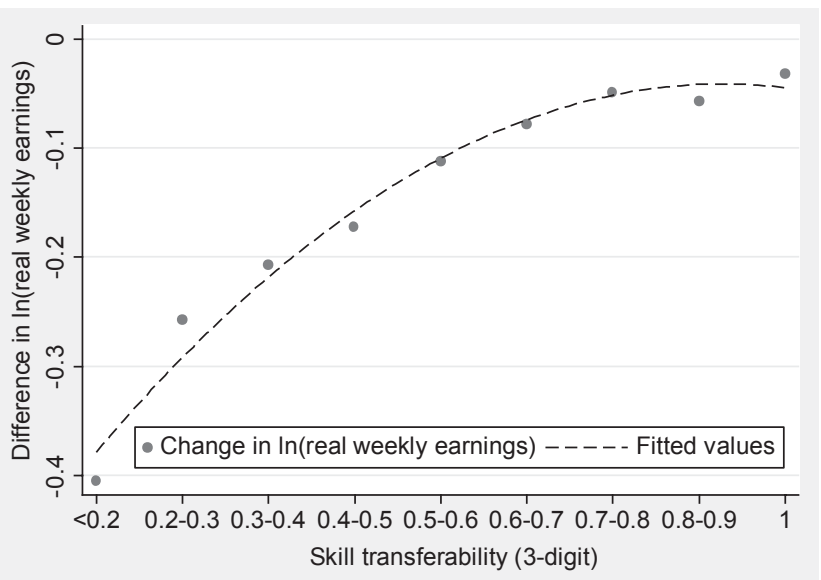

Fig. 2 The average change in $\ln$ (real weekly earnings) by level of occupational skills transferability between pre- and post-displacement occupations

more-or-less similar jobs. Thus, Fig. 2 provides descriptive evidence to support the hypotheses outlined above, and they motivate the idea of assessing the importance of occupational human capital and inter-occupational variation as a determinant of earnings losses as a result of job displacement.

\section{Estimation results}

\subsection{OLS regression results}

While Fig. 2 suggests that the ability to transfer occupational skills to a new job can reduce earnings losses following job displacement, the relationship may change when we control for observable characteristics. The empirical results from the OLS regression shown in Table 5 highlight the effects of key independent variables on earnings losses of displaced workers. The parameter of interest is the coefficient on the transferability of occupational human capital ( Transfer $\left._{i, l c}\right){ }^{21}$

Column (1) of Table 5 is the standard model of occupational human capital and earnings losses, and it is similar to those used by prior studies. In this model, occupational human capital is captured by a dichotomous variable indicating whether the displaced worker remained in the same 3-digit occupation (SAMEOCC). This estimated coefficient represents the effect of occupation-specific human capital on earnings losses if workers lose all occupation-specific skills when they are displaced and reemployed in a new occupation. Consistent with the previous studies, the regression result presents that, on average, staying in the same 3-digit

\footnotetext{
${ }^{21}$ The results in Table 5 are unweighted. We also apply the weighted regression using the CPS final sampling weights, and the results do not differ importantly from those shown in Table 5.
}

occupation lowers earnings losses by 10.50 percentage points, all else equal. In addition, staying in the same 3-digit industry also lowers earnings losses by 8.30 percentage points, all else equal. ${ }^{22}$ The expected earnings loss of displaced workers who stay in their occupation and industry at the sample mean of worker characteristics is approximately 8.04 percentage points; the expected earnings loss of workers who only stay in their industry but change occupation is approximately 18.52 percentage points; the expected earnings loss of workers who only stay in their occupation but change industries is approximately 16.38 percentage points, and the expected earnings loss of workers who are displaced from both occupation and industry is approximately 26.86 percentage points. This implies that skills that are specific to occupation and industry are important to the determination of earnings losses.

In column (2), we substitute the skills transferability (Transfer ${ }_{i, l c}$ ) - the continuous measure of occupational human capital, which ranges from 0 to 1 - for the dummy variable of switching occupations (SAMEOCC) to ascertain the effect of the skills transferability across occupations. There is a very strong association between occupational skills transferability and earnings losses. In particular, if skills transferability increases by 10 percentage points, on average, it reduces real weekly earnings losses by 3.6 percentage points, holding other factors fixed, and the estimated coefficient is statistically significant at the $1 \%$ level. Also, the magnitude of the coefficient of switching industries is reduced to 6.4 percentage points. Thus, this finding indicates a positive and strong relationship between the decline of earnings losses and occupational matches after job displacement, consistent with Schönberg and Gathmann's (2010) finding. For example, consider the estimated earnings losses of two displaced workers, both of whom worked as HR managers. One finds a new job as a sales manager, and the other becomes a baker. The skills transferability from the HR manager position to the sales manager position is equal to 0.8661 ( $86.61 \%$ of the HR skills transferred to the sales manager position), and the skills transferability from the HR manager position to the baker occupation is equal to 0.1593 (15.93\% of the HR skills transferred to the baker occupation). According to these estimates, the expected earnings loss due to the loss of skills transferability of the worker who was displaced from the HR manager and reemployed as the sales manager was lower than the expected earnings loss of the other, who switched from the HR manager position to the baker occupation, by 28.0 percentage points.

In addition to the effect of occupational skills transferability, there is also a strong relationship between pre-displacement work history and subsequent earnings losses. For ${ }^{22}$ The $R^{2}$ and estimated coefficients of other variables in the model are
also consistent with the previous studies. 
Table 5 The earnings losses regression for the full sample

\begin{tabular}{|c|c|c|c|c|}
\hline \multirow[t]{2}{*}{ Independent variable } & \multicolumn{4}{|c|}{ Dependent variable: difference in log of real weekly earnings ( $\$ 2010 ;$ OLS) } \\
\hline & $(1)$ & $(2)$ & $(3)$ & $(4)$ \\
\hline \multirow[t]{2}{*}{ Same occupation $(0 / 1)$} & 0.105 & & & -0.004 \\
\hline & $(6.28)$ & & & $(-0.09)$ \\
\hline \multirow[t]{2}{*}{ Same industry $(0 / 1)$} & 0.083 & 0.064 & 0.072 & 0.072 \\
\hline & $(4.73)$ & $(3.62)$ & $(4.03)$ & $(4.06)$ \\
\hline \multirow[t]{2}{*}{ Transferability*100 } & & 0.0036 & 0.0093 & 0.0091 \\
\hline & & $(9.37)$ & $(3.12)$ & $(2.21)$ \\
\hline \multirow[t]{2}{*}{ Transferability $^{2}$} & & & -0.00004 & -0.00004 \\
\hline & & & $(-1.99)$ & $(-1.19)$ \\
\hline \multirow[t]{2}{*}{ Firm tenure (at the lost job) } & -0.008 & -0.008 & -0.008 & -0.008 \\
\hline & $(-5.08)$ & $(-4.91)$ & $(-4.91)$ & $(-4.91)$ \\
\hline \multirow[t]{2}{*}{ Union status (at the lost job, 0/1) } & -0.121 & -0.122 & -0.123 & -0.123 \\
\hline & $(-3.64)$ & $(-3.69)$ & $(-3.70)$ & $(-3.70)$ \\
\hline \multirow[t]{2}{*}{ Advanced notice $(0 / 1)$} & 0.014 & 0.011 & 0.010 & 0.010 \\
\hline & $(0.84)$ & $(0.62)$ & $(0.60)$ & $(0.60)$ \\
\hline \multirow[t]{2}{*}{ Health insurance (at the lost job, 0/1) } & -0.001 & -0.004 & -0.003 & -0.003 \\
\hline & $(-0.07)$ & $(-0.20)$ & $(-0.15)$ & $(-0.15)$ \\
\hline \multirow[t]{2}{*}{ UI benefit $(0 / 1)$} & -0.043 & -0.045 & -0.045 & -0.045 \\
\hline & $(-2.43)$ & $(-2.51)$ & $(-2.53)$ & $(-2.53)$ \\
\hline \multirow[t]{2}{*}{ UI ended $(0 / 1)$} & -0.194 & -0.186 & -0.185 & -0.185 \\
\hline & $(-6.64)$ & $(-6.38)$ & $(-6.36)$ & $(-6.36)$ \\
\hline \multirow[t]{2}{*}{ State unemployment } & 0.000 & 0.000 & 0.000 & 0.000 \\
\hline & $(-0.05)$ & $(-0.05)$ & $(-0.03)$ & $(-0.03)$ \\
\hline \multirow[t]{2}{*}{ Full-time job (at the lost job, 0/1) } & -0.313 & -0.314 & -0.315 & -0.315 \\
\hline & $(-9.08)$ & $(-9.10)$ & $(-9.12)$ & $(-9.12)$ \\
\hline \multirow[t]{2}{*}{ Age } & 0.015 & 0.014 & 0.015 & 0.015 \\
\hline & $(2.54)$ & $(2.47)$ & $(2.49)$ & $(2.49)$ \\
\hline \multirow[t]{2}{*}{$\mathrm{Age}^{2}$} & -0.0002 & -0.0002 & -0.0002 & -0.0002 \\
\hline & $(-3.02)$ & $(-2.97)$ & $(-2.98)$ & $(-2.98)$ \\
\hline \multirow[t]{2}{*}{ Female } & -0.089 & -0.092 & -0.094 & -0.094 \\
\hline & $(-4.35)$ & $(-4.51)$ & $(-4.58)$ & $(-4.58)$ \\
\hline$N$ & 6827 & 6827 & 6827 & 6827 \\
\hline Adj. $R^{2}$ & 0.0778 & 0.0845 & 0.0850 & 0.0849 \\
\hline
\end{tabular}

t-Statistics are in the parentheses. Not included as independent variables are 10 major occupation dummies, 10 major industry dummies, marital status, US citizen dummy, race dummies (i.e., black, white, Hispanic), dummy of geographic moves, unemployment rate at year of survey across state, year of displacement, and four education levels

example, the coefficient of firm tenure at the lost job is negative and statistically significant. This highlights the importance of specialized skills that accumulate over time within a firm and are lost when changing jobs. Specifically, two additional years of tenure at a previous firm, on average, increased earnings losses by 1.60 percentage points, holding other variables fixed. This finding is consistent with other studies of the importance of firm-specific human capital that have found that workers will lose all the skills specific to a particular firm when they change to a new employer (Podgursky and Swaim 1987; Carrington 1990; Topel 1990).

The coefficient on individual workers' union membership at a pre-displacement job is negative and statistically significant at the $1 \%$ level, indicating that unionized workers suffer larger earnings losses than the nonunionized workers. The earnings losses of displaced workers who collected unemployment insurance benefits were significantly greater than those who did not collect the benefit by 4.50 percentage points, all else equal. Also, displaced workers whose UI benefit had already been exhausted suffered greater earnings losses than those whose benefit was still available. The estimated coefficient of the state unemployment rate is very small and statistically insignificant at the $5 \%$ level. This implies there is no strong evidence to support that local market conditions can explain some of the earnings losses encountered by displaced workers. One plausible explanation is that state unemployment is not sufficient to explain the local labor market condition, and other measures are more relevant. For example, Carrington (1993) applied several measures that closely control for the 
status of the industrial, occupational, and geographical labor market from which the workers were displaced, including the employment in state by one-digit occupation and industry, and he found that these local labor market measures can also explain some of the wage losses encountered by displaced workers. ${ }^{23}$

The coefficients of the remaining independent variables have the expected signs. For example, displaced workers working full time at the lost job were more likely to suffer a greater decline in earnings by 31.40 percentage points relative to what they earned before they were displaced. The earnings losses of workers who were informed in advance about their job displacement were not statistically significant from those who were not informed in advance. Also, as mentioned above, we use age (and $a g e^{2}$ ) together with the education level as a proxy for the number of years of market experience. The coefficients of both age and $a g e^{2}$ are statistically significant at the $5 \%$ level, which implies that the number of years of general market experience, on average, helps lower the earnings losses.

As indicated in Fig. 2, the relationship between the occupational skills transferability and earnings losses might not be linear. Column (3), therefore, represents the results from Eq. 4, which includes the quadratic form of skills transferability $\left(\right.$ Transfer $\left._{i, i c}^{2}\right)$. The results show that both linear and quadratic terms of skills transferability are individually statistically significant at the $5 \%$ level. The F-test for the significance of both linear and quadratic forms of skills transferability indicates that these two variables are highly jointly significant $(\mathrm{F}=15.84, p<0.0001)$. In addition, the quadratic term has a negative value, implying that skills transferability reduces earnings losses at a decreasing rate. Compared with column (1), replacing the occupational change dummy with the skills transferability variables improves the prediction power of the model $\left(R^{2}\right)$ from 7.80 to $8.50 \%$. However, most of other control variables are slightly affected by this replacement. For example, the estimated coefficient of switching 3-digit industries is lowered from 0.083 to 0.072 .

Following Eq. 3, column (4) includes both types of measures of occupational human capital (i.e., Transfer $_{i, l c}$, Trans$f e r^{2}{ }_{i, l c}$ and SAMEOCC). The results show that when skills transferability (Transfer ${ }_{i, l_{c}}$ and Transfer $_{i, l c}^{2}$ ) is included in the model together with the dummy variable indicating switching occupations (SAMEOCC), the coefficient of SAMEOCC drops from 0.105 to -0.004 and becomes statistically insignificant at the $5 \%$ level, while the magnitude of each coefficient of skills transferability is still large and statistically

\footnotetext{
${ }^{23}$ As a robustness test, we also ran a separate regression using the sample during the recession periods between 2008 and 2010, and the results in general look quite similar to those in the full sample. In particular, the estimated coefficient of state unemployment is still statistically insignificant at the $5 \%$ level.
}

Table 6 The earnings losses regression based on the 2-and 1-digit occupation levels

\begin{tabular}{|c|c|c|c|}
\hline \multirow[t]{2}{*}{ Independent variable } & \multicolumn{3}{|c|}{$\begin{array}{l}\text { Dependent variable: difference } \\
\text { in log of real weekly earnings } \\
(\$ 2010 ; \text { OLS })\end{array}$} \\
\hline & $(1)$ & $(2)$ & (3) \\
\hline Same occupation (2-digit) & $\begin{array}{l}0.124 \\
(7.49)\end{array}$ & & \\
\hline Same industry (2-digit) & $\begin{array}{l}0.081 \\
(4.84)\end{array}$ & $\begin{array}{l}0.072 \\
(4.29)\end{array}$ & $\begin{array}{l}0.076 \\
(4.53)\end{array}$ \\
\hline Transferability*100 (2-digit) & & $\begin{array}{l}0.0035 \\
(9.25)\end{array}$ & $\begin{array}{l}0.0134 \\
(2.91)\end{array}$ \\
\hline Transferability $^{2}$ (2-digit) & & & $\begin{array}{l}-0.0001 \\
(-2.17)\end{array}$ \\
\hline$N$ & 6827 & 6827 & 6827 \\
\hline Adj. $R^{2}$ & 0.0818 & 0.0854 & 0.0861 \\
\hline Same occupation (1-digit) & $\begin{array}{l}0.116 \\
(6.69)\end{array}$ & & \\
\hline Same industry (1-digit) & $\begin{array}{l}0.089 \\
(5.2)\end{array}$ & $\begin{array}{l}0.086 \\
(5.09)\end{array}$ & $\begin{array}{l}0.086 \\
(5.07)\end{array}$ \\
\hline Transferability*100 (1-digit) & & $\begin{array}{l}0.028 \\
(7.18)\end{array}$ & $\begin{array}{l}0.0034 \\
(0.67)\end{array}$ \\
\hline Transferability $^{2}$ (1-digit) & & & $\begin{array}{l}0.0000 \\
(-0.12)\end{array}$ \\
\hline$N$ & 6827 & 6827 & 6827 \\
\hline Adj. $R^{2}$ & 0.0810 & 0.0819 & 0.0818 \\
\hline
\end{tabular}

t-Statistics are in the parentheses

significant at the $5 \%$ level. Compared with the standard model in column (1), the adjusted $R^{2}$ increases from 7.78 to $8.49 \%$ in column (4), indicating that skills transferability captures a slightly greater variation in earnings losses than the dummy variable of switching occupations. The F-test for the significance of both linear and quadratic forms of skills transferability also indicates that these two variables are highly jointly significant $(\mathrm{F}=10.34, p<0.0001)$, which implies that both forms of skills transferability add information to the model. This finding confirms the above hypothesis that skills transferability across occupations is a better measure of occupational human capital than the dummy variable of switching occupations. In other words, the effect of the dummy variable is captured by the skills transferability so that measuring the occupational human capital in terms of the degree of similarity between two occupations is more important than whether or not workers can find the same occupations as their previous jobs. ${ }^{24}$

\footnotetext{
${ }^{24}$ As suggested by an anonymous referee, we also estimate an additional specification similar to those in columns (2) and (3) in Table 5, except we exclude the dummies for major occupations and industries as well as a dummy for remaining in the same 3-digit industry from the analysis. Overall, the results changed only slightly compared with when we included those dummy variables. For example, the coefficient of skills transferability (Transfer ${ }_{i, l c}$ ) is 0.004 without those dummy variables, compared with 0.0036 with those dummy variables. In addition, including these sets of dummies increased the adjusted $R^{2}$ of the model from 8.17 to $8.45 \%$.
} 
As a robustness check, Table 6 presents the estimated coefficients of occupational human capital measures, similar to columns (1) to (3) in Table 5, based on the 2- and 1-digit occupation levels. Overall, the results look very similar to those in the 3-digit level. For example, staying in the same 2-digit occupation lowers earnings losses by 12.40 percentage points, all else equal, while staying in the same 2 -digit industry also lowers earnings losses by 8.15 percentage points, all else equal. The estimated coefficients of linear and quadratic terms of skills transferability, based on the 2-digit occupation, are also statistically significant at the $5 \%$ level. Note that the 1-digit estimated coefficients of linear and quadratic terms of skills transferability (Transfer ${ }_{i, l}$ and $\operatorname{Transfer}_{i, l c}^{2}$ ) are individually statistically insignificant at the $5 \%$ level. However, the F-test for the significance of both linear and quadratic forms of skills transferability indicates that these two variables are highly jointly significant $(\mathrm{F}=25.74, p<0.0001)$.

\subsection{Selection bias correction}

The results from the previous section present a strong relationship between earnings losses due to job displacement and occupational similarity as measured by skills transferability. However, as mentioned earlier, OLS estimates may be subject to selection bias because the process of reemployment is not random. The relationship between skills transferability and earnings losses in a sample of displaced workers who are reemployed at the survey date might be quite different from the relationship observed in the labor force as a whole. For example, those who were not reemployed may have had different unobserved characteristics affecting their earnings from those of reemployed group. If this is the case, the OLS method could produce biased and inconsistent estimates.

One way to reduce the source of selection bias is to restrict the sample to workers who were displaced at least 1 year before the survey date because those workers displaced in the most recent years are less likely to be reemployed and hence report their weekly earnings (Neal 1995). Table 7 presents the OLS results for this group of workers. Even though this restriction lowered the sample size by approximately $37 \%$, the estimated transferability effect is very similar to those reported in Table 5. For example, column (2) shows that increasing the skills transferability by 10 percentage points, on average, lowers earnings losses by 3.8 percentage points, all else equal.

Thus, the results corrected for selection bias also support the hypothesis that displaced workers are compensated for occupation-specific skills, and workers who find occupations that are more similar to their pre-displacement jobs will suffer less earnings losses than those who find dissimilar occupations, thus confirming the importance of occupational human capital as a major determinant of earnings losses.
Table 7 The OLS results for workers who were displaced at least 1 year before the survey date

\begin{tabular}{|c|c|c|c|c|}
\hline \multirow[t]{2}{*}{ Independent variable } & \multicolumn{4}{|c|}{$\begin{array}{l}\text { Dependent variable: difference in log of } \\
\text { real weekly earnings ( } \$ 2010 \text {; OLS) }\end{array}$} \\
\hline & $(1)$ & $(2)$ & (3) & (4) \\
\hline \multirow[t]{2}{*}{ Same occupation $(0 / 1)$} & 0.108 & & & -0.015 \\
\hline & $(4.75)$ & & & $(-0.28)$ \\
\hline \multirow[t]{2}{*}{ Same industry $(0 / 1)$} & 0.099 & 0.079 & 0.087 & 0.088 \\
\hline & $(3.99)$ & $(3.25)$ & $(3.54)$ & $(3.55)$ \\
\hline \multirow[t]{2}{*}{ Transferability*100 } & & 0.0038 & 0.0105 & 0.0096 \\
\hline & & (7.99) & $(3.27)$ & $(2.12)$ \\
\hline \multirow[t]{2}{*}{ Transferability $^{2}$} & & & -0.00005 & -0.00004 \\
\hline & & & $(-2.09)$ & $(-1.07)$ \\
\hline \multirow{2}{*}{$\begin{array}{l}\text { Firm tenure (at the } \\
\text { lost job) }\end{array}$} & -0.010 & -0.010 & -0.010 & -0.010 \\
\hline & $(-5.87)$ & $(-5.74)$ & $(-5.73)$ & $(-5.72)$ \\
\hline \multirow{2}{*}{$\begin{array}{l}\text { Union status (at the } \\
\text { lost job, } 0 / 1 \text { ) }\end{array}$} & -0.136 & -0.138 & -0.138 & -0.139 \\
\hline & $(-3.61)$ & $(-3.69)$ & $(-3.70)$ & $(-3.70)$ \\
\hline \multirow[t]{2}{*}{ Advanced notice $(0 / 1)$} & -0.003 & -0.007 & -0.007 & -0.007 \\
\hline & $(-0.17)$ & $(-0.34)$ & $(-0.35)$ & $(-0.36)$ \\
\hline \multirow{2}{*}{$\begin{array}{l}\text { Health insurance (at } \\
\text { the lost job, 0/1) }\end{array}$} & -0.006 & -0.009 & -0.008 & -0.008 \\
\hline & $(-0.27)$ & $(-0.38)$ & $(-0.35)$ & $(-0.35)$ \\
\hline \multirow[t]{2}{*}{ UI benefit $(0 / 1)$} & 0.007 & 0.007 & 0.007 & 0.007 \\
\hline & $(0.28)$ & $(0.28)$ & $(0.29)$ & $(0.29)$ \\
\hline \multirow[t]{2}{*}{ UI ended $(0 / 1)$} & -0.206 & -0.196 & -0.194 & -0.194 \\
\hline & $(-7.03)$ & $(-6.71)$ & $(-6.66)$ & $(-6.66)$ \\
\hline \multirow{2}{*}{$\begin{array}{l}\text { Full-time Job (at the } \\
\text { lost job, } 0 / 1 \text { ) }\end{array}$} & -0.295 & -0.297 & -0.299 & -0.299 \\
\hline & $(-7.93)$ & $(-8.02)$ & $(-8.06)$ & $(-8.06)$ \\
\hline \multirow[t]{2}{*}{ Age } & 0.013 & 0.011 & 0.012 & 0.012 \\
\hline & $(1.83)$ & (1.68) & (1.69) & (1.69) \\
\hline \multirow[t]{2}{*}{$\mathrm{Age}^{2}$} & -0.0002 & -0.0002 & -0.0002 & -0.0002 \\
\hline & $(-2.45)$ & $(-2.31)$ & $(-2.31)$ & $(-2.31)$ \\
\hline \multirow[t]{2}{*}{ Female } & -0.093 & -0.094 & -0.096 & -0.096 \\
\hline & $(-4.10)$ & $(-4.17)$ & $(-4.26)$ & $(-4.25)$ \\
\hline$N$ & 4308 & 4308 & 4308 & 4308 \\
\hline Adj. $R^{2}$ & 0.0882 & 0.0969 & 0.0976 & 0.0974 \\
\hline
\end{tabular}

t-Statistics are in the parentheses. Independent variables not presented are 10 major occupation dummies, 10 major industry dummies, marital status, U.S. citizen dummy, race dummies (i.e., black, white, Hispanic), dummy of geographic moves, unemployment rate at year of survey across state, year of displacement, and four education levels

\section{Further analysis}

According to the correlation (Table 4), we can see that occupational skills transferability has a positive correlation with the pre-displacement earnings. Table 8 , therefore, provides further analysis of the OLS regression highlighting the effects of occupational similarity on the pre-displacement earnings. Column (1) shows that, on average, displaced workers staying in the same 3-digit occupation or industry have higher pre-displacement earnings, holding other factors constant. The estimated coefficient of skills transfer- 
Table 8 The effect of occupational human capital on pre-displacement earnings

\begin{tabular}{|c|c|c|c|}
\hline \multirow[t]{2}{*}{ Independent variable } & \multicolumn{3}{|c|}{$\begin{array}{l}\text { Dependent variable: log of pre-displace- } \\
\text { ment weekly earnings ( } \$ 2010 ; \text { OLS) }\end{array}$} \\
\hline & (1) & (2) & (3) \\
\hline Same occupation $(0 / 1)$ & $\begin{array}{l}0.081 \\
(6.10)\end{array}$ & & \\
\hline Same industry $(0 / 1)$ & $\begin{array}{l}0.058 \\
(3.96)\end{array}$ & $\begin{array}{l}0.051 \\
(3.51)\end{array}$ & $\begin{array}{l}0.050 \\
(3.40)\end{array}$ \\
\hline Transferability* 100 & & $\begin{array}{l}0.002 \\
(8.16)\end{array}$ & $\begin{array}{l}0.001 \\
(0.69)\end{array}$ \\
\hline Transferability $^{2}$ & & & $\begin{array}{l}0.0000 \\
(0.51)\end{array}$ \\
\hline Firm tenure (at the lost & 0.007 & 0.007 & 0.007 \\
\hline & $(7.09)$ & $(7.27)$ & $(7.27)$ \\
\hline Union status (at the lost & 0.132 & 0.131 & 0.131 \\
\hline & $(6.35)$ & $(6.27)$ & $(6.28)$ \\
\hline Advanced notice $(0 / 1)$ & $\begin{array}{l}0.010 \\
(0.76)\end{array}$ & $\begin{array}{l}0.007 \\
(0.58)\end{array}$ & $\begin{array}{l}0.007 \\
(0.58)\end{array}$ \\
\hline Health insurance (at the & 0.251 & 0.251 & 0.250 \\
\hline & (17.98) & (17.94) & $(17.91)$ \\
\hline UI benefit $(0 / 1)$ & $\begin{array}{l}0.037 \\
(2.86)\end{array}$ & $\begin{array}{l}0.037 \\
(2.79)\end{array}$ & $\begin{array}{l}0.037 \\
(2.80)\end{array}$ \\
\hline UI ended $(0 / 1)$ & $\begin{array}{l}-0.002 \\
(-0.13)\end{array}$ & $\begin{array}{l}0.003 \\
(0.15)\end{array}$ & $\begin{array}{l}0.003 \\
(0.15)\end{array}$ \\
\hline State unemployment & $\begin{array}{l}0.016 \\
(4.24)\end{array}$ & $\begin{array}{l}0.016 \\
(4.27)\end{array}$ & $\begin{array}{l}0.016 \\
(4.26)\end{array}$ \\
\hline $\begin{array}{l}\text { Full-time job (at the lost } \\
\text { job, 0/1) }\end{array}$ & $\begin{array}{l}0.682 \\
(27.13)\end{array}$ & $\begin{array}{l}0.681 \\
(27.09)\end{array}$ & $\begin{array}{l}0.681 \\
(27.1)\end{array}$ \\
\hline Age & $\begin{array}{l}0.039 \\
(9.80)\end{array}$ & $\begin{array}{l}0.039 \\
(9.75)\end{array}$ & $\begin{array}{l}0.039 \\
(9.74)\end{array}$ \\
\hline $\mathrm{Age}^{2}$ & $\begin{array}{l}-0.0004 \\
(-8.68)\end{array}$ & $\begin{array}{l}-0.0004 \\
(-8.63)\end{array}$ & $\begin{array}{l}-0.0004 \\
(-8.62)\end{array}$ \\
\hline Female & $\begin{array}{l}-0.182 \\
(-12.91)\end{array}$ & $\begin{array}{l}-0.184 \\
(-13.07)\end{array}$ & $\begin{array}{l}-0.183 \\
(-13.04)\end{array}$ \\
\hline$N$ & 6827 & 6827 & 6827 \\
\hline Adj. $R^{2}$ & 0.5482 & 0.5501 & 0.5501 \\
\hline
\end{tabular}

$\mathrm{t}$-Statistics are in the parentheses. Not included as independent variables are 10 major occupation dummies, 10 major industry dummies, marital status, US citizen dummy, race dummies (i.e., black, white, Hispanic), dummy of geographic moves, unemployment rate at year of survey across state, year of displacement, and four education levels

ability in column (2) shows a very strong linear association between occupational skills transferability and pre-displacement earnings. In particular, if skills transferability increases by 10 percentage points, on average, the predisplacement earnings are higher by around $2.0 \%$, holding other factors fixed. Note that there is no statistical evidence of a non-linear relationship between the skills transferability and pre-displacement earnings, since both linear and quadratic forms of skills transferability (Transfer $r_{i, l c}$ and Trans- $\left.\mathrm{fer}^{2}{ }_{i, I c}\right)$ are individually statistically insignificant at the $5 \%$ level (see column (3)). However, the F-test for the significance of both linear and quadratic forms of skills transferability indicates that these two variables are highly jointly significant $(\mathrm{F}=33.58, p<0.0001)$. These results, therefore, imply that displaced workers who have been successful in their previous job more frequently manage to find another job that is close to their previous occupational demands and, therefore, suffer less earnings losses.

\section{Conclusions and implications for future research}

This paper highlights the role of occupational human capital in determining the earnings losses after job displacement; in particular, the degree to which occupation-specific skills are transferable across occupations depends on the similarity between two given occupations. The key finding of this paper is that occupational human capital, and more specifically skills transferability between occupations, is an important determinant of changes in weekly earnings following displacement. In particular, the ordinary least square (OLS) estimates present that, on average, 10 additional units of skills transferability between pre- and postdisplacement occupations lowers earning losses by 3.6 percentage points ceteris paribus. It implies that the degree of similarity between pre- and post-displacement occupations has a strong effect on how displaced workers will suffer from earnings losses both in terms of significance and the magnitude of the effect. This goes beyond the usual finding from most of the previous studies using the dichotomous "change-in-occupation" variable. In addition, the relationship between occupational skills transferability and earnings losses are not linear: a higher degree of skills transferability lowers earnings losses, but the decline attenuates as skills transferability increases. Moreover, the results from the further analysis show a strong and positive relationship between the degree of occupational similarity and the predisplacement earnings.

However, one of the limitations from this study comes from the fact that the ability of job losers is not so random and is likely to be correlated with the (unconditional) change in earnings. In particular, it may be that a worker who is relatively good at his job (i.e., the tasks associated with the job) will be more likely to find a job similar to his previous occupation and to earn more. In contrast, a worker who is not good at his job (and the tasks associated with the job) will be less likely to find a similar job to his previous occupation. Thus, the worker will earn less partly because he could not apply some skills in the new job. The selection bias correction model may only solve the endogeneity problem of reemployment, but not the one of displacement. Thus, perhaps the more appropriate conclusion of the study 
would be among the re-employed displaced workers, those who find an occupation more similar to the lost job, suffer the smaller earnings losses because (1) they can use their specific skills in the new job, (2) they had more of the specific skills (and that is why they found a more similar job), (3) they were better at the types of skills in the similar job. Unfortunately, we cannot distinguish these views based on the DWS.

While not without limitation, the findings in this paper still significantly enhance our understanding of the importance of occupational human capital, particularly skills transferability in earnings losses determination. This paper's findings on earnings losses due to job displacement have important implications for researchers, policy makers, and the public. For future research, it sheds light on the role of occupational human capital in determining earnings losses after job displacement. In fact, the results show that displaced workers also receive compensation that is not completely general or specific to a particular firm, but rather specific to occupation. The findings from this paper highlight the importance of occupational specific human capital in the employment relationship; losing these types of skills might result in substantial losses to the displaced worker's earnings. In addition, previous research on this topic used a dummy variable indicating whether displaced workers remained in the same occupation as their pre-displacement job and ignored the fact that occupational skills could be (partially) transferable across occupations. However, using the continuous variable of skills transferability, the results from this paper indicate that if displaced workers could find occupations that are very similar, if not exactly the same, as their old jobs, they could transfer most of their previous occupational skills to the new job and their earnings losses would be reduced. Moreover, the findings present that the measure of skills transferability is a better measure of occupational human capital than the dummy variable of switching occupations. Thus, those performing future research regarding occupational human capital should consider applying this measure to other outcome variables as well. For example, this paper only examines the effect of occupational skill transferability on the loss of earnings between pre- and post-displacement occupations and does not consider the effect on other types of benefits. Thus, it might be interesting for future research to investigate the effect of occupational human capital, especially the skills transferability, on total compensation, which also includes other benefits such as health insurance and pension (Podgursky and Swaim 1987).

\section{Kurzfassung}

Den Kosten von Arbeitsplatzverlusten wurden in den vergangenen Jahrzehnten von Politikern und Forschern viel
Aufmerksamkeit gewidmet. Die jüngste Rezession und der daraus resultierende dramatische Anstieg an unfreiwilligen Arbeitsplatzverlusten haben das Interesse an diesem Thema noch gesteigert. Millionen von Arbeitnehmern im besten Alter verloren ihren Arbeitsplatz und diejenigen, die das Glück hatten, eine Anstellung zu finden, mussten häufig wesentlich niedrigere Verdienste hinnehmen.

Das Ziel dieser Arbeit ist es, die Auswirkungen akkumulierten Humankapitals, insbesondere beruflichen Humankapitals, auf Einkommensverluste zu untersuchen. Im Speziellen, in welchem Maße beeinflusst die Ähnlichkeit von Beschäftigungen vor und nach dem Arbeitsplatzverlust die Einkommensverluste der freigesetzten Arbeitskräfte? Wir stellen die Hypothese auf, dass die Einkommensverluste in Verbindung mit dem Arbeitsplatzverlust durch den Grad beeinflusst werden, in welchem berufsbezogene Kenntnisse über Beschäftigungen hinweg übertragen werden können. Unter wiederbeschäftigten Arbeitskräften prognostizieren wir, dass diejenigen, die in eine näherliegende (ähnlichere) Beschäftigung wechseln, geringere Einkommensverluste haben werden, als diejenigen, die in artfremde Beschäftigungen wechseln, da sie weniger ihrer berufsspezifischen Kenntnisse verlieren. Abweichend zu den meisten früheren Studien zu Arbeitsplatzverlusten nutzen wir die durchgängige Messgröße der Übertragbarkeit beruflicher Kenntnisse, um die Ähnlichkeit von Beschäftigungen vor und nach dem Arbeitsplatzverlust von wiederbeschäftigten freigesetzten Arbeitskräften zu messen.

Unter Nutzung der Displaced Worker Survey (DWS) der Jahre 2004, 2006, 2008 und 2010 zeigen die wichtigsten Erkenntnisse dieser Arbeit, dass Einkommensverluste nach einem Arbeitsplatzverlust eine starke Korrelation mit dem Ähnlichkeitsgrad zwischen den Beschäftigungen vor und nach dem Arbeitsplatzverlust aufweisen. Freigesetzte Arbeitskräfte, die Beschäftigungen finden, die, gemessen an der Übertragbarkeit beruflicher Kenntnisse, ihren früheren Beschäftigungen ähneln, haben geringere Einkommensverluste als diejenigen, die weniger ähnliche Beschäftigungen finden. Darüber hinaus ist diese Beziehung nicht linear: eine größere Übertragbarkeit von Kenntnissen reduziert Einkommensverluste in sinkendem Maße. Die weitere Analyse zeigt außerdem die positive Beziehung zwischen Einkommen vor dem Arbeitsplatzverlust und dem Grad beruflicher Ähnlichkeit. Diese Erkenntnisse liefern wichtige Einblicke in die Bestimmung von Einkommensverlusten aufgrund von Arbeitsplatzverlusten. Diese Untersuchung leistet insbesondere von einem theoretischen Standpunkt aus einen Beitrag zur Humankapitalliteratur, indem die Bedeutung des beruflichen Humankapitals und die Vorstellung, dass berufliche Kenntnisse (teilweise) über Beschäftigungen hinweg übertragbar sind, hervorgehoben werden. 


\section{Appendix}

Table 9 Knowledge, skill, and ability categories across occupations as defined by $\mathrm{O} * \mathrm{NET}$

\begin{tabular}{|c|c|c|}
\hline Knowledge & Skill & Ability \\
\hline $\begin{array}{l}\text { Administration } \\
\text { and management }\end{array}$ & Active learning & Arm-hand steadiness \\
\hline Biology & Active listening & Auditory attention \\
\hline $\begin{array}{l}\text { Building and } \\
\text { construction }\end{array}$ & $\begin{array}{l}\text { Complex problem } \\
\text { solving }\end{array}$ & Category flexibility \\
\hline Chemistry & Coordination & Control precision \\
\hline Clerical & Critical thinking & Deductive reasoning \\
\hline $\begin{array}{l}\text { Communications } \\
\text { and media }\end{array}$ & $\begin{array}{l}\text { Equipment } \\
\text { maintenance }\end{array}$ & Depth perception \\
\hline $\begin{array}{l}\text { Computers and } \\
\text { electronics }\end{array}$ & Equipment selection & Dynamic flexibility \\
\hline $\begin{array}{l}\text { Customer and } \\
\text { personal service }\end{array}$ & Installation & Dynamic strength \\
\hline Design & Instructing & Explosive strength \\
\hline $\begin{array}{l}\text { Economics and } \\
\text { accounting }\end{array}$ & $\begin{array}{l}\text { Judgment and deci- } \\
\text { sion making }\end{array}$ & Extent flexibility \\
\hline $\begin{array}{l}\text { Education and } \\
\text { training }\end{array}$ & Learning strategies & Far vision \\
\hline $\begin{array}{l}\text { Engineering and } \\
\text { technology }\end{array}$ & $\begin{array}{l}\text { Management of finan- } \\
\text { cial resources }\end{array}$ & Finger dexterity \\
\hline English language & $\begin{array}{l}\text { Management of mate- } \\
\text { rial resources }\end{array}$ & Flexibility of closure \\
\hline Fine arts & $\begin{array}{l}\text { Management of per- } \\
\text { sonnel resources }\end{array}$ & Fluency of ideas \\
\hline Food production & Mathematics & Glare sensitivity \\
\hline Foreign language & Monitoring & $\begin{array}{l}\text { Gross body } \\
\text { coordination }\end{array}$ \\
\hline Geography & Negotiation & $\begin{array}{l}\text { Gross body } \\
\text { equilibrium }\end{array}$ \\
\hline $\begin{array}{l}\text { History and } \\
\text { archeology }\end{array}$ & Operation and control & Hearing sensitivity \\
\hline $\begin{array}{l}\text { Law and } \\
\text { government }\end{array}$ & Operation monitoring & Inductive reasoning \\
\hline Mathematics & Operation analysis & Information ordering \\
\hline Mechanical & Persuasion & Manual dexterity \\
\hline $\begin{array}{l}\text { Medicine and } \\
\text { dentistry }\end{array}$ & Programming & $\begin{array}{l}\text { Mathematical } \\
\text { reasoning }\end{array}$ \\
\hline $\begin{array}{l}\text { Personnel and } \\
\text { human resources }\end{array}$ & $\begin{array}{l}\text { Quality control } \\
\text { analysis }\end{array}$ & Memorization \\
\hline $\begin{array}{l}\text { Philosophy and } \\
\text { theology }\end{array}$ & $\begin{array}{l}\text { Reading } \\
\text { comprehension }\end{array}$ & $\begin{array}{l}\text { Multilimb } \\
\text { coordination }\end{array}$ \\
\hline Physics & Repairing & Near vision \\
\hline $\begin{array}{l}\text { Production and } \\
\text { processing }\end{array}$ & Science & Night vision \\
\hline Psychology & Service orientation & Number facility \\
\hline $\begin{array}{l}\text { Public safety and } \\
\text { security }\end{array}$ & Social perceptiveness & Oral comprehension \\
\hline $\begin{array}{l}\text { Sales and } \\
\text { marketing }\end{array}$ & Speaking & Oral expression \\
\hline $\begin{array}{l}\text { Sociology and } \\
\text { anthropology }\end{array}$ & System analysis & Originality \\
\hline $\begin{array}{l}\text { Telecommunica- } \\
\text { tions }\end{array}$ & System evaluation & Perceptual speed \\
\hline $\begin{array}{l}\text { Therapy and } \\
\text { counseling }\end{array}$ & Technology design & Peripheral vision \\
\hline
\end{tabular}

Table 9 (Continued)

\begin{tabular}{|c|c|c|}
\hline Knowledge & Skill & Ability \\
\hline Transportation & $\begin{array}{l}\text { Time management } \\
\text { Troubleshooting } \\
\text { Writing }\end{array}$ & $\begin{array}{l}\text { Problem sensitivity } \\
\text { Rate control } \\
\text { Reaction time } \\
\text { Response orientation } \\
\text { Selective attention } \\
\text { Sound localization } \\
\text { Spatial orientation } \\
\text { Speech clarity } \\
\text { Speech recognition } \\
\text { Speed of closure } \\
\text { Speed of limb } \\
\text { movement } \\
\text { Stamina } \\
\text { Static strength } \\
\text { Time sharing } \\
\text { Trunk strength } \\
\text { Visual color } \\
\text { discrimination } \\
\text { Visualization } \\
\text { Wrist-finger speed } \\
\text { Written } \\
\text { comprehension } \\
\text { Written expression }\end{array}$ \\
\hline
\end{tabular}

Table 10 Descriptive statistics of displaced workers (2004-2010)

\begin{tabular}{lll}
\hline Variable & Mean & SD \\
\hline Difference in the natural logarithm of real & -0.21 & 0.68 \\
weekly earnings (in \$2010) & & \\
Difference in the real weekly earnings (in & -121.15 & 454.86 \\
\$2010) & & \\
Weekly earnings at the lost job & 773.68 & 625.93 \\
Weekly earnings at the current job & 685.01 & 575.42 \\
Occupational skills transferability & 75.44 & 21.95 \\
Same occupation $(0 / 1)$ & 0.33 & 0.47 \\
Same industry $(0 / 1)$ & 0.29 & 0.45 \\
Female $(0 / 1)$ & 0.44 & 0.50 \\
Age & 39.43 & 11.25 \\
Less than high school $(0 / 1)$ & 0.07 & 0.26 \\
High school $(0 / 1)$ & 0.33 & 0.47 \\
Some college degree $(0 / 1)$ & 0.34 & 0.47 \\
College degree $(0 / 1)$ & 0.20 & 0.40 \\
Advanced degree $(0 / 1)$ & 0.07 & 0.25 \\
Years of firm tenure at the lost job & 4.81 & 6.23 \\
Union status at the lost job (0/1) & 0.09 & 0.28 \\
Married $(0 / 1)$ & 0.56 & 0.50 \\
Advanced notice $(0 / 1)$ & 0.36 & 0.48 \\
Health insurance at the lost job $(0 / 1)$ & 0.58 & 0.49 \\
UI benefit $(0 / 1)$ & 0.43 & 0.50 \\
UI ended $(0 / 1)$ & 0.14 & 0.35 \\
U.S. citizen $(0 / 1)$ & 0.93 & 0.26 \\
Moved geographically $(0 / 1)$ & 0.15 & 0.35 \\
Full-time at the lost job (0/1) & 0.90 & 0.31 \\
White $(0 / 1)$ & 0.75 & 0.44 \\
Black (0/1) & 0.09 & 0.28 \\
Hispanic $(0 / 1)$ & 0.12 & 0.32 \\
\hline & & \\
& &
\end{tabular}


Table 10 (Continued)

\begin{tabular}{|c|c|c|}
\hline Variable & Mean & SD \\
\hline Year of displacement $=2009(0 / 1)$ & 0.11 & 0.32 \\
\hline Year of displacement $=2008(0 / 1)$ & 0.10 & 0.30 \\
\hline Year of displacement $=2007(0 / 1)$ & 0.14 & 0.35 \\
\hline Year of displacement $=2006(0 / 1)$ & 0.07 & 0.25 \\
\hline Year of displacement $=2005(0 / 1)$ & 0.13 & 0.34 \\
\hline Year of displacement $=2004(0 / 1)$ & 0.07 & 0.26 \\
\hline Year of displacement $=2003(0 / 1)$ & 0.18 & 0.38 \\
\hline Year of displacement $=2002(0 / 1)$ & 0.10 & 0.30 \\
\hline Year of displacement $=2001(0 / 1)$ & 0.10 & 0.30 \\
\hline State unemployment rate & 6.23 & 2.31 \\
\hline \multicolumn{3}{|l|}{ Major occupation } \\
\hline Management (0/1) & 0.14 & 0.35 \\
\hline Professional $(0 / 1)$ & 0.17 & 0.37 \\
\hline Service $(0 / 1)$ & 0.11 & 0.32 \\
\hline Sales $(0 / 1)$ & 0.10 & 0.30 \\
\hline Clerical $(0 / 1)$ & 0.15 & 0.36 \\
\hline Farming, fishing, and forestry $(0 / 1)$ & 0.01 & 0.07 \\
\hline Construction $(0 / 1)$ & 0.10 & 0.30 \\
\hline Installation, maintenance, and repair $(0 / 1)$ & 0.05 & 0.22 \\
\hline Production $(0 / 1)$ & 0.11 & 0.31 \\
\hline Transportation $(0 / 1)$ & 0.07 & 0.25 \\
\hline \multicolumn{3}{|l|}{ Major industry } \\
\hline Agriculture $(0 / 1)$ & 0.01 & 0.08 \\
\hline Mining $(0 / 1)$ & 0.01 & 0.09 \\
\hline Manufacturing $(0 / 1)$ & 0.20 & 0.40 \\
\hline Wholesale and retail trade $(0 / 1)$ & 0.15 & 0.35 \\
\hline Information $(0 / 1)$ & 0.04 & 0.19 \\
\hline Financial $(0 / 1)$ & 0.08 & 0.27 \\
\hline Professional and business services $(0 / 1)$ & 0.13 & 0.34 \\
\hline Educational and health services $(0 / 1)$ & 0.11 & 0.31 \\
\hline
\end{tabular}

Table 11 Descriptive statistics for sampled DWS and Full DWS (2004-2010)

\begin{tabular}{llllll}
\hline Variable & \multicolumn{2}{l}{ Full DWS } & & \multicolumn{2}{l}{ Sampled DWS } \\
\cline { 2 - 3 } & Mean & SD & & Mean & SD \\
\hline Female $(0 / 1)$ & 0.44 & 0.50 & & 0.44 & 0.50 \\
Weekly pay at the current & 677.47 & 598.44 & & 685.01 & 575.42 \\
job $(\$)$ & & & & \\
Age & 41.13 & 13.01 & & 39.43 & 11.25 \\
Less than high school $(0 / 1)$ & 0.10 & 0.30 & & 0.07 & 0.26 \\
High school $(0 / 1)$ & 0.34 & 0.47 & & 0.33 & 0.47 \\
Some college $(0 / 1)$ & 0.31 & 0.46 & & 0.33 & 0.47 \\
College $(0 / 1)$ & 0.18 & 0.38 & & 0.20 & 0.40 \\
Advanced college $(0 / 1)$ & 0.07 & 0.26 & & 0.07 & 0.25 \\
Married $(0 / 1)$ & 0.53 & 0.50 & & 0.56 & 0.50 \\
White $(0 / 1)$ & 0.70 & 0.46 & 0.75 & 0.44 \\
Black $(0 / 1)$ & 0.11 & 0.31 & 0.09 & 0.28 \\
Number of workers & 27,540 & & 6827 & \\
\hline
\end{tabular}

DWS Displaced Worker Survey
Acknowledgments We would like to thank Dale Belman, Todd Elder, Peter Berg, Mary Hamman, Liqiu Zhao, Christian Pfeifer, and two anonymous referees for offering helpful comments and suggestions. We also thank all seminar participants at Renmin University of China and Michigan State University. All remaining errors are ours.

\section{References}

Becker, G.S.: Human Capital, University of Chicago Press, Chicago (1964)

Burda, M. and Mertens, A.: Estimating wage losses of displaced workers in Germany. Labour Econ. 8,15-41 (2001)

Carrington, W.J.: Specific human capital and worker displacement. Ph.D. Dissertation, University of Chicago (1990)

Carrington, W.J.: Wage losses for displaced workers: Is it really the firm that matters? J. Hum. Resour. 28,435-462 (1993)

Couch, K.: Earnings losses and unemployment of displaced workers in Germany. Ind. Labor Relat. Rev. 54,559-572 (2001)

Evans, D.S., Leighton, L.S.: Retrospective bias in the Displaced Worker Surveys. J. Hum. Resour. 30,386-396 (1995)

Farber, H.S.: The Incidence and Costs of Job Loss: 1982-91. Brookings Papers on Economic Activity: Microeconomics 1,73-132 (1993)

Hijzen, A., Upward, R., Wright, P.: The income losses of displaced workers. J. Hum. Resour. 45,243-269 (2010)

Hutchens, R.: Seniority, wages and productivity: a turbulent decade. J. Econ. Perspect. 3,49-64 (1989)

Jacobson, L.S., LaLonde, R., Sullivan, D.: Earnings losses of displaced workers. Am. Econ. Rev. 83,685-709 (1993)

Kambourov, G., Manovskii, I.: A cautionary note on using (March) CPS data to study worker mobility. Mimeo, The University of Pennsylvania (2004)

Kambourov, G., Manovskii, I.: Occupational specificity of human capital. Int. Econ. Rev. 50,63-115 (2009)

Kletzer, L.G.: Job displacement. J. Econ. Perspect. 12,115-136 (1998)

Kletzer, L.G., Fairlie, R.W.: The long-term costs of job displacement for young adult workers. Ind. Labor Relat. Rev. 56,682-698 (2003)

Lazear, E.P.: Why is there mandatory retirement? J. Political Econ. 87,1261-1284 (1979)

Lazear, E.P.: Agency, earnings, profiles, productivity, and hours restrictions. Am. Econ. Rev. 71,606-620 (1981)

Podgursky, M., Swaim, P.: Job displacement and earnings loss: evidence from the Displaced Worker Survey. Ind. Labor Relat. Rev. 41,17-29 (1987)

Nawakitphaitoon, K.: Occupational human capital and wages: the role of skills transferability across occupations. J. Labor Res. 35,63-87 (2014)

Neal, D.: Industry-specific human capital: evidence from displaced workers. J. Labor Econ. 13,653-677 (1995)

Ormiston, R.: Displaced manufacturing workers and occupation-specific human capital. Dissertation, Michigan State University

Ruhm, C.J.: Are workers permanently scarred by job displacements? Am. Econ. Rev. 81,319-324 (1991)

Schönberg, U., Gathmann, C.: How general is human capital? A taskbased approach, J. Labor Econ. 28,1-50 (2010)

Shaw, K.L.: A formulation of the earnings function using the concept of occupational investment. J. Hum. Resour. 19,319-340 (1984)

Topel, R.: Specific capital and unemployment: measuring the costs and consequences of job loss. Carnegie-Rochester Conf. Ser. Pub. Policy. 33,181-214 (1990)

Topel, R.: Specific capital, mobility, and wages: wages rise with job seniority. J. Political Econ. 99,145-175 (1990) 
Kritkorn Nawakitphaitoon is an assistant professor at School of Labor and Human Resources at Renmin University of China. He received his Master degree in economics from University of Illinois at Urbana-Champaign in 2006, and received his doctorate in Labor Relations and Human Resources, with majors in Labor Economics from Michigan State University in 2012. His research interests are concentrated in the areas of labor economics, microeconomics, and applied econometrics. The main focus of his research is on the topic of occupational human capital.
Russell Ormiston is an assistant professor of economics at Allegheny College in Meadville, Pennsylvania, USA. His research interests include labor economics, sports economics and human resource management. 